\title{
Is the Westernization Process Losing Pace in Turkey: Who's to Blame?
}

\section{Tarik Oğuzlu \& Mustafa Kibaroğlu}

To cite this article: Tarik Oğuzlu \& Mustafa Kibaroğlu (2009) Is the Westernization Process Losing Pace in Turkey: Who's to Blame?, Turkish Studies, 10:4, 577-593, DOI: 10.1080/14683840903384836

To link to this article: http://dx.doi.org/10.1080/14683840903384836

册 Published online: 10 Dec 2009.

Submit your article to this journal $\pi$

Llll Article views: 348

Q View related articles ¿

Citing articles: 7 View citing articles $\square$ 
Vol. 10, No. 4, 577-593, December 2009

\title{
Is the Westernization Process Losing Pace in Turkey: Who's to Blame?
}

\author{
TARIK OĞUZLU \& MUSTAFA KİBAROĞLU \\ Department of International Relations, Bilkent University, Ankara, Turkey
}

\begin{abstract}
The logic of interest, which has gained considerable ground in foreign policy formulation in Turkey, is not rooted in Western identity, nor is it contingent upon the degree of interaction exclusively with the Western world. The entire world has equal prominence in Turkey's foreign policy orientation. Whether the prevalence of the logic of interest in the formulation of Turkish foreign policy under the "post-Islamist" AKP government signifies a deviation from the Westernization process or whether it is simply a reaction to the conjunctural developments in the international arena in order to preserve Turkey's national interests is seriously debated. This paper aims to contribute to this debate by shedding light on the background of developments both inside and outside Turkey.
\end{abstract}

\section{Introduction}

History and geography affect the foreign policies of states, as does type of political regime, ideological disposition, national threat perception, alliance commitment, and economic need. However, these are more variable and less durable factors when compared to history and geography, the impact of which may be far greater and longer-term. History and geography may have had an even greater impact on the formulation of Turkish foreign policy because of the highly strategic geographical location of Turkey and its much-cherished history as the heir of the Ottoman Empire.

The modern Republic of Turkey was founded on October 29, 1923, out of the ashes of the Ottoman Empire following the War of Liberation against the occupying powers under the command of Mustafa Kemal Atatürk. ${ }^{1}$ The fundamental principles of the foreign policy of the new Republic were laid out by Atatürk as its founder and first president. Atatürk's objective was to elevate Turkey to the rank of highly civilized nations, which were at that time mostly found in the West. Therefore, the term "Westernization" has been used for decades to denote the fundamental orientation of Turkey in its foreign relations.

The Westernization process was primarily conceived as a way to contribute to the improvement of Turkey's security at home and abroad. ${ }^{2}$ This inherent security-driven

Correspondence Address: Tarık Oğuzlu, Department of International Relations, Bilkent University, 06800, Bilkent, Ankara, Turkey. Email: oguzlu@bilkent.edu.tr. 
mentality becomes evident when one considers the fact that the Ottoman Empire had already launched a reformation and restructuring process with the Tanzimat movement in the early nineteenth century, when it was militarily and economically outpaced by the European powers. ${ }^{3}$

In the early 1920s, in accordance with the goal of elevating the young Turkish Republic to the rank of highly civilized nations in the world, Atatürk set into motion comprehensive reforms that were perfectly compatible with the goal of Westernization. These reforms, however, were so radical and intensive that they shook the foundations of traditional Ottoman/Turkish society and injected a strong ideational soul to the initially fear-driven Westernization process. Since then, the assertion of a Western identity has greatly affected the logic of Turkish foreign policy formulation.

A clear-cut example of this was Turkey's eagerness to become a member of the North Atlantic Treaty Organization (NATO), which occurred in 1952. Turkey did not mind that the Middle East was considered "out-of-area" in the contingency planning of its military alliance. Bitter memories of World War I, during which the Arab communities under Ottoman rule collaborated with Great Britain and France (who partitioned the imperial territories), have left deep traces in the mindset of most Turks. The net effect of this development was the total denial of Middle Eastern politics by the young Turkish Republic and an effort to dissociate itself from the region for as long as it could. Similarly, Turkey's endeavors to become an associate or full member in European institutions - the European Union in particular - since the early 1960s, indicates its fascination with being treated as European in the international arena. Against this background it would be safe to say that the "logic of identity" has dominated foreign policy in the Republic of Turkey since its foundation.

Nevertheless, since the end of the Cold War, and more so in the new millennium, interest-based calculations have gained considerable ground in the logic of foreign policy formulation in Turkey. Yet, this "logic of interest" is not contingent upon the degree of interaction exclusively with the Western world. The entire world, including the Middle East, now has equal prominence in Turkey's foreign policy orientation. Globalization and the rapidly changing international environment may have been powerful factors in widening the scope of Turkey's foreign policy agenda. However, a number of significant developments in the political and economic realms in Turkey, culminating in the rise of the Justice and Development Party (Adalet ve Kalkınma Partisi, AKP) in the November 2002 general elections, have been more influential in yielding such an outcome. ${ }^{4}$

Whether the prevalence of the logic of interest in the formulation of Turkish foreign policy under the so-called "post-Islamist" AKP government ${ }^{5}$ signifies a deviation from the fundamental principles presented by Atatürk in the 1920s (such as Westernization) or whether it is simply a reaction to the conjunctural developments in the international arena in order to preserve Turkey's national interests, is a seriously debated issue in the country. Hence, this paper contributes to this debate by shedding light on the background of the developments both inside and outside of Turkey. 
This paper begins with brief descriptions of the logic of fear, the logic of identity, and the logic of interest, which were significant ideas in the formulation of Turkish foreign policy. Then it proceeds with a discussion on how and why the foreign policy behaviors of the Western nations towards Turkey affected the logic that prevailed in different periods. More emphasis is placed on relations between Turkey and Western Europe because of the longer history of these relations and their geographical proximity. However, the impact of relations with the United States on the formulation of Turkey's foreign policy is also included in the scope of this paper because the role of security considerations and, therefore, the role that the Turkish military played in the formulation of Turkish foreign policy cannot be overlooked or underestimated.

The paper then offers an analysis of the factors that paved the way to the dominance of the logic of interest. The impact of developments that have taken place in the political, economic, and military spheres, both inside and outside of Turkey, that are thought to be responsible for such an outcome are thus elaborated in detail.

The paper concludes by addressing the challenges that even the logic of interest has been confronting since the beginning of the twenty-first century, primarily due to the attitude of the West - the European Union and the United States combinedand by arguing that unless the West seriously considers these challenges, they are likely to cause a profound deviation from the traditional orientation of Turkish foreign policy, which may, in turn, have repercussions for the West.

\section{Turkey's Approach to the West: Alternative Logics at Play}

From a conceptual perspective one can explain Turkey's approach to the West in general and its adoption of the EU's norms in particular from three alternative logics, namely the logic of fear, the logic of identity, and the logic of interest.

\section{The Logic of Fear}

The logic of fear suggests that Turkey strives to become a member of the West out of security-related concerns. These concerns are twofold: to avoid the possibility that the West would define Turkey as a potential threat and thus interfere with its internal affairs, and to seek help from the West against other external threats. Based on Ottoman-era experiences, the founding fathers of the Turkish Republic concluded that eliminating the fears of exclusion, dismemberment, and encirclement would be possible through the implementation of Western-oriented reforms at home and the pursuit of closer security cooperation with Western European states abroad. ${ }^{6}$ Arising from the logic of fear, joining the European international society as a legitimate power was crucial for Turkey in order to avoid the real danger of being threatened by Europe. The implication of this union for domestic politics was that forming a unitary and homogenous nation-state at home was necessary in order to avoid external interference in Turkey's internal affairs because, in the past, the Western powers had successfully used Christian minorities in their efforts to 
manipulate the decisions of the Porte (the Istanbul government) and to impose their own visions.

\section{The Logic of Identity}

The logic of identity suggests that the transformation of Turkey's identity in line with the constitutive norms of the West is considered legitimate at home and that Turkey would willingly pay the costs of harmonization with the West. The early modernization attempts during the 1920s were undertaken with a view to accelerating Turkey's transformation into a Western-style secular nation-state, where not only state and religion would be institutionally separated from each other (objective secularization) but also where people would gradually view religion as a private issue between themselves and God (subjective secularization). ${ }^{7}$ As it was believed that modernization would lead to migration from rural to urban areas, growing literacy rates, ongoing industrialization, and the abolition of feudal societal relations, the public role of Islam would be limited. Through modernization would come the increased ability of the center to help shape society from above and to create a community of citizens out of a community of Muslim people who were the subjects of the Ottoman Sultan. Ethnic, religious, and linguistic differences would gradually lose value in shaping peoples' identities. Pursuing ethnicity politics would be seen as illegitimate, as the principle of constitutional-territorial citizenship would define the boundaries of national identity. The degree of Turkey's socialization into Western norms would be highest if Turkey approached the West from a logic of identity.

\section{The Logic of Interest}

The logic of interest suggests that Turkey adopts the constitutive norms of the West to the extent that they help Turkey to achieve its pre-determined national interests. If the benefits of socialization into Western norms exceeded the costs, this process would continue. The more Turkey is believed to benefit from the continuation of the Westernization/Europeanization process the longer it would be willing to pay the costs of becoming a Western/European country.

\section{The Logic of the Western/European Approach towards Turkey}

Concepts of the logic of identity and the logic of interest can also be used to explain the West's attitude towards Turkey. The logic of identity adopted in the Western world has indeed two versions, one of which simply suggests that a country cannot become a legitimate member of the West unless it is perceived to share the unchangeable constitutive aspects of Western identity. Proponents of this logic, therefore, argue that there is no way for Turkey to join the EU, as Turkey is not Christian, does not share Europe's Greco-Roman cultural and historical heritage, and is not geographically located on the European continent. The second version of the logic of identity in the West, however, suggests that the EU is more a political than 
cultural project and that the EU's identity should rely on universal principles of liberalism, democracy, respect for human rights, and constitutionalism. To these proponents, Turkey's membership in the EU could materialize if and when Turkey adheres fully to these norms. These are attainable characteristics, and there are no a priori obstacles in front of Turkey to internalize them. Proponents of the logic of interest in the West suggest that Turkey's membership in the EU should be contingent on the sum of the costs and benefits of such an action. If the benefits of Turkey's inclusion exceed the benefits of its exclusion, particularly measured in terms of economic, political, and military considerations, the EU should let Turkey in.

During the Cold War era, both logics could have justified Turkey's standing in Western institutions for two main reasons. First, Western identity was mainly defined with respect to opposition to the East, namely the communist bloc led by the Soviet Union. As such, Turkey's Western identity was not contested, thanks to its membership in NATO. Second, Turkey's membership in NATO served the interest of the West, particularly in its efforts to contain Soviet expansionism towards Western Europe, the Balkans, and the Middle East.

Nevertheless, the dynamics of the relationship between Turkey and the EU in the post-Cold War era have proved unsatisfactory in terms of identity-related considerations. Turkey's recognition as a Western or a European country has become difficult, as the Central and Eastern European countries appear to be truly European when compared to Turkey in terms of the fundamental aspects of Western/European identity. Furthermore, Turkey's growing troubles with liberal democracy and the protection of human rights at home tied the hands of those who might have fought for Turkey's inclusion in the EU based on its cosmopolitan, universal norms.

In addition, justifying Turkey's inclusion in the EU in terms of interest-related considerations has become difficult, if not impossible. Many Europeans question Turkey's relevance to Europe's security in the absence of the colossal Soviet threat. Turkey has increasingly been seen as an ally that could potentially contribute to Western security within the context of Middle Eastern politics. However, the more Turkey's relevance to the West emanates from its Middle Eastern connections, the more its European identity has become contested. Not only has Turkey's performance in meeting the EU accession criteria become the most important element defining the legitimacy of Turkey's European identity; the idea that Turkey's security assets would facilitate its accession to the EU also eventually lost its value. ${ }^{8}$

The perception of Turkey as a buffer zone between Europe and the unstable Middle East has hindered the chances of Turkey's eventual EU membership. ${ }^{9}$ This idea, coupled with the EU's growing focus on the Central and Eastern European countries, has led to suggestions that Turkey's membership might slow the integration process. ${ }^{10}$ While the former communist countries of Central and Eastern Europe were offered credible chances for inclusion in the EU, Turkey was informally thought to be satisfied with a privileged status. The Luxembourg decisions in December 1997, stating that Turkey was not eligible for membership, demonstrated growing reluctance in EU circles to include Turkey. Even the confirmation of Turkey's candidacy in 1999 and the formal start of accession talks in late 2005 did 
not radically improve Turkey's status; the EU tied Turkey's eventual accession to many conditions including, inter alia, the EU's absorption capacity and the affirmative votes of European nationals. Besides, the EU made it clear that accession negotiations would involve an open-ended process in which the outcome could not be predicted beforehand. ${ }^{11}$

Moreover, the EU's approach towards Turkey has not changed for the better in the wake of the September 11 attacks and the US-led war in Iraq. Paradoxically, since the EU started accession talks in late 2005, voices against Turkey's inclusion in the EU have begun to be heard more often and much louder. ${ }^{12}$

The EU's decision to start accession talks with Turkey was mainly informed by interest-related considerations. As EU members debated among themselves about the appropriateness of such a decision, the overwhelming view in the EU capitals was that both Turkey and the EU would undergo significant changes by the time Turkey joined the EU. Given that the eventual accession would not take place until the 2020s, shutting the door in Turkey's face now would not be a rational action. By the time accession actually happened, both the EU's absorption capacity would increase and the degree of Turkey's internal and external Europeanization would be strengthened.

Despite the fact that the start of accession talks institutionally brought Turkey closer to the EU, the optimistic mood among the Turks and the Europeans has taken a negative turn. Suspicions of Turkey's unsuitability for membership have grown. European public opinion has also been growing wary of the presence of the Muslim community in the EU. It is almost certain that if the question of Turkey's eventual accession were put to public referenda, overwhelming majorities in countries such as Austria and France would likely cast negative votes. ${ }^{13}$

In the post-September 11 period, objections to Turkey's membership on the basis of identity-related considerations have increased while the arguments in favor of Turkish accession on the basis of cost-benefit calculations have lost ground. With the rise of "Islamophobic" sentiments across the European continent, coupled with growing societal security concerns over the existence of approximately 20 million Muslims, the EU has increasingly become reluctant to develop a strong geopolitical commitment to the Middle East or to Turkey's eventual accession. ${ }^{14}$ The European circles that traditionally advocated Turkey's inclusion on the basis of the EU's multicultural and secular identity have also lost some weight, given Turkey's democratization performance, which has fluctuated since 2006.

On the other hand, the EU has begun to view the "war on terror" strategy, launched by the United States in the aftermath of the September 11 attacks, as more harmful than beneficial for the security of Europe. Such a view may be another reason why involvement in Middle Eastern affairs is seen as illegitimate in the European capitals. ${ }^{15}$ The risk here is that if EU officials adopt the view that the best strategy to avoid the dangers of transnational terrorism would be to play "the deaf and the blind," the EU's commitments to Middle Eastern stability might decrease. Disengagement of the EU from the Middle East would potentially put Turkey in limbo regarding its European aspirations as it would reduce the prospects of Turkey's accession to the EU. 
Given that one of the significant ways for Turkey to register its European identity would pass through its attempts to demonstrate its relevance to European security within the Middle Eastern context, the EU's disengagement from the Middle East would render Turkey's potential contributions meaningless. Unlike the EU, Turkey's involvement in the Middle East has deepened, as Turkey's internal security depends on what happens in the region. The worry here is that the growing salience of the Middle East in Turkish foreign policy might prompt the Europeans to believe that Turkey is more a Middle Eastern country than a European one.

\section{Role of US Policies in Diluting Turkey's Claims for Western/European Identity}

Similar to the developments on the European front, Turkey has also grown discontent with the changing dynamics of its relationship with the United States and NATO in the aftermath of the dissolution of the Soviet Union. Ankara and Washington have searched for new grounds on which to continue their alliance relationship. The transformation of NATO from a trans-Atlantic/Western collective defense organization into a semi-political, semi-military global collective security organization has rendered Turkey's efforts to claim its Western/European identitythanks to her alliance membership_more difficult than ever. Rather, Turkey's membership in NATO seems to be based more on the understanding that Turkey is a Middle Eastern country whose primary role is to help the West project its values onto the "Greater Middle Eastern" region. ${ }^{16}$

Whereas the United States would have liked to rely on Turkey's geopolitical and military assets in the Greater Middle Eastern region, in the post-Cold War era Turkey would have preferred to be valued by Washington in the context of the security of Europe. ${ }^{17}$ Otherwise, Turkey's potential contributions to US/NATO interests in the Greater Middle Eastern region might have mistakenly led observers to conclude that Turkey was simply a Middle Eastern country and not a European one. Such Turkish concerns became noticeable when the United States asked Turkey to let the Americans use NATO's capabilities in out-of-area missions. Such requests created enormous pressure on Turkey because Turkey's permission would suggest that the Turks had accepted the new reasoning that if NATO did not go out-of-area it would go out-of-business. ${ }^{18}$

Developments in the post-September 11 era have also underlined the Middle Eastern aspects of Turkey's identity among Western powers. For instance, Turkey was considered to be a "model" for the moderate Islamic regimes in the Middle East that lived in harmony with the Western powers. Moreover, there was a constitutive relationship between the quality of security in the West and the quality of governance in the developing world. ${ }^{19}$ Hence the promotion of liberal democracies and good governance in the Middle East was thought to be necessary for the security strategy of the West.

Notwithstanding the expectation of Europeans and Americans of Turkey in regard to its capacity to offer a model for the states in the Greater Middle Eastern region to emulate their efforts to transform themselves into liberal democracies, 
such an argument was seen by Turks to further erode the credentials of Turkey's Western/European identity. The more the suggestion that Turkey offers a successful example of the peaceful cohabitation between Islam and democracy, the more concerned Turkey's secular elites felt. To these elites, Turkey is first and foremost a secular state in which Islam can in no way be mentioned in defining the state's identity. The American claim that Islam and democracy can coexist suggests that Islam is a social force shaping people's identity. Seen from this perspective, the legitimacy of the ideational logic towards the West, particularly on the part of Turkey's Kemalist security elites, has increasingly been contested. ${ }^{20}$ The more the West sees Turkey's transformation into a moderate Islamic country as being in its security interests the more this view might accelerate Turkey's Islamization process at home. ${ }^{21}$

\section{Turkey Embraces the Logic of Interest in its Foreign Relations}

Due to the ambiguous attitude of the EU towards Turkey, the makers of Turkish foreign policy apparently doubted that the EU's goal was to keep Turkey in its orbit forever without offering prospects for full membership. Thus, the prime motivation behind relations with the EU has become to secure Turkey's national interest, which, at times contradicted that of the European powers. ${ }^{22}$ One particular reason for such an outcome has been Turkey's concern-and the perceived reluctance of the West throughout the 1990s-to accelerate integration into the EU. Hence, the adoption of the logic of interest towards the EU over the logic of identity or the logic of fear can be seen as a reaction of the Turks to the slow-motion integration strategy, in the minds of the Europeans.

The changes that Turkey went through the 1990s constitute another factor that may have caused the adoption of the logic of interest towards the West. In those years, new, popular social classes began to replace older ones as the center of economic activity gradually shifted from Istanbul to Anatolia. Growing economic power on the part of the Anatolian bourgeoisie resulted in demands for the redistribution of political privileges. As they became economically more powerful these new classes demanded more political representation. ${ }^{23}$ The more representation they acquired the more they tried to change the substance of Turkish foreign policy interests to their own image. Turkey's growing integration into the global markets has resulted in the formation of a new understanding, according to which Turkey should take utmost care to contribute to achieving peaceful and stable relations in its region. Regional instability would delay Turkey's economic development and stymie the country's efforts to integrate successfully into the global economy.

Uninterrupted economic growth at home increasingly required the emergence of stable and peaceful regions in Turkey's neighborhood. In this sense, Turkey's efforts to contribute to the emergence of regional stability in the Middle East, particularly in the post-September 11 era, by playing a facilitator role and acting as a European country in non-European geographies contributing to regional integration and peaceful settlement of perennial disputes has been a rational strategy, rather 
than one aimed at pleasing the EU. ${ }^{24}$ Moreover, the more economy oriented Turkish foreign policy has become, the more legitimate has Eurasian identity been seen in Turkey. The hope was that Turkey's capability to materialize its economic development at home as well as to reach out to its neighborhood would become much easier if Turkey defined itself as a Eurasian country rather than as one whose number one foreign policy interest is to join the EU. ${ }^{25}$ The emergence of Turkey's Eurasian identity, coupled with a pragmatic approach towards the West, has been affected by a series of domestic developments.

First, with growing liberal democracy at home, civilians and elected politicians have increasingly become more important than appointed bureaucrats (particularly those in the military and diplomatic circles) in the formulation of Turkey's foreign and security policies. The more the civilians have gained ground, the more Turkey's adoption of an ambitious foreign policy has become observable. Despite the military establishment's inclination to preserve the status quo and to counsel caution, civilians have tended to adopt more daring ideology-driven attitudes to situations abroad. In other words, while the military has tried to preserve Turkey's gains, civilians have endeavored to enlarge Turkey's sphere of influence on Eurasia. ${ }^{26}$

Second, as the liberal democratization process continued, interest groups vied to influence Turkish foreign policy in accordance with their particular interests and ideologies. The growing salience of societal input has caused a multidimensional Turkish foreign policy. The most important ideological stance that has shaped the emerging foreign policy consensus is that Turkey is a regional actor in its own right and should define its interests, independent of its institutional links to the Western international community. Rather than looking outside through the prisms of the West, this new stance suggests that Turkey should make use of its links to the West in pursuing its interests abroad. Instead of trying to prove its value to the West by contributing to the materialization of Western security interests in its neighborhood, the prevailing view was that Turkey should adopt an instrumental approach towards the West. In other words, the Westernization/Europeanization process should continue so long as the links to the West enhance Turkey's capability for projecting its power.

A third factor that caused the adoption of the logic of interest towards the West was the victories of the AKP in the parliamentary elections in 2002 and 2007. The AKP government has begun to view the EU accession process from an instrumental perspective in the sense that the value of this process has increasingly depended on its relevance to the materialization of Turkey's economic interests abroad. This fact becomes evident if one takes into account the AKP government's argument that the EU accession process contributes to the improvement of Turkey's domestic stability and leads rich foreign investors from Western and Gulf countries to come and invest in the Turkish economy. ${ }^{27}$ The institutional identity of the AKP has made the adoption of the logic of interest much easier. Despite the fact that the AKP does not share the EU-skeptic approach of the Welfare Party (Refah Partisi, RP), which used to say that "the EU is a Christian club and Turkey should not join it if it wants to preserve its Islamic identity," the AKP leadership does not believe that Western/European norms symbolize the climax of human development. ${ }^{28}$ 
It is worth mentioning in this regard that the AKP considers Turkey to belong both to European and Islamic civilizations. Participating in the "Alliance of Civilization" initiative under the aegis of the United Nations fully fits into this mentality. Instead of first adopting the EU's norms and identity and then acting as the representative of the EU in the Middle East, the AKP appears to think that Turkey should rather represent the Islamic civilizations within the EU. Just as the start of the accession process with the EU helped improve Turkey's soft-power standing in the eyes of Islamic nations, the AKP leadership also believes that Turkey's growing security, and cultural and economic links with the Middle East will increase the prospects of that country's accession to the EU.

Equally significant is that the AKP differentiates between the continuation of the accession process with the EU and membership itself. That it pays more attention to the former recently became obvious when the AKP leadership announced: "Turkey would continue to undertake the liberal-democratic reforms even if the EU suspended the accession negotiations." 29 Comparing the reactions of the government of Mesut Yilmaz (then the leader of the Motherland Party (Anavatan Partisi, ANAP)) to the EU decision (taken at the Luxembourg Summit meeting in December 1997) to exclude Turkey from the enlargement rounds, the AKP's reaction to the EU decision in December 2006 to partially suspend the accession talks over eight specific chapters was as mild as one could imagine. This attitude is a reflection of the logic of interest adopted in formulating Turkey's foreign policy.

\section{The Logic of Interest Challenged}

As the incompatibilities between Turkey and the West become more apparent, even the logic of interest, which prevailed in the formulation of Turkish foreign policy towards the West, was challenged for a number of reasons. ${ }^{30}$

First, as the internalization of the EU's Copenhagen criteria appeared to be the main decisive factor for Turkey's inclusion in the West, fear that Turkey would transform into a multicultural, decentralized, and federal polity increased at home. The EU's request that Turkey define the Kurdish and the Alevite (non-Sunni Muslim) citizens of Turkey as minority groups who were eligible for positive discrimination caused anxiety among both the Kemalist elite and AKP government circles. The growing demand from the West that Turkey find a political solution to the Kurdish problem at home provided justification for the erosion of the logic of interest. Such calls appear to overlook the fact that the resolution of PKK (Kurdistan Workers' Party) terrorism is not possible without accounting for what has been happening in northern Iraq following the overthrow of Saddam Hussein's regime. The US-led war in Iraq has made it crystal clear that the developments in the region seriously affect Turkey's internal security complex, mainly because Kurds in Turkey might be increasingly attracted to the emerging Kurdish nationalism in northern Iraq. It is worth mentioning that the gains of northern Iraqi Kurds seem to have emboldened the Kurdish Democratic Society Party (Demokratik Toplum Partisi, DTP) in Turkey to argue for Turkey's transformation into a "democratic 
republic," whereby Turks and Kurds would constitute the "two founding communities." Given such developments, the EU-led liberal democratic reforms created anxiety at home. Despite the growing European and US demands that Turkey define Kurds as a minority group entitled to positive discrimination Turkish consensus holds that the resolution of the Kurdish problem would be possible by way of improvement of human rights in an individual sense. ${ }^{31}$

Second, Turkey's frustration with the Europeanization process has grown because the European Union has not kept its promise of easing trade restrictions on the Turkish Republic of Northern Cyprus following the latter's overwhelming support of the "Annan Plan" in April 2004. ${ }^{32}$ Rather than keeping its promise to Turkish Cypriots the EU partially suspended accession negotiations with Turkey in December 2006 over eight specific chapters on the grounds that Turkey did not open its sea and airports to the Greek Cypriot naval vessels and airplanes. Greek Cypriots did not support the Annan Plan yet they were admitted to the EU as full members. The fact that the Greek Cypriots could easily manipulate the institutional mechanisms of the EU against Turkey has been perceived by Ankara as an example of the growing EU reluctance to accept Turkey.

Third, while the EU emphasized Turkey's deficiencies in the field of human rights and minorities it did not put equal stress on its secular character. This fact has caused some in Ankara to ask if the EU's behind-the-curtain intention was to help Turkey transform into an Islamizing country so that the question of Turkey's suitability for membership would drop off the agenda once and for all. This possible intention reminded many Turks of the European powers' approach towards the Ottoman Empire during the late nineteenth and early twentieth centuries. ${ }^{33}$

Fourth, a growing number of Europeans now loudly argue that non-membership alternatives should be offered to Turkey. For example, German Chancellor Angela Merkel suggests Turkey's attachment to the EU through the formation of a privileged partnership. During the November 2007 congress of the Christian Democratic Party in Germany the suggestion to offer Turkey a privileged partnership status was written into the official party documents. Similarly, French President Nicolas Sarkozy claimed that Turkey should be included in a French-led Mediterranean Union rather than the EU. ${ }^{34}$ In the same vein, the Turkish public has grown unhappy with the emergence of the idea that the EU's absorption capacity should be one of the criteria for membership, if and when Turkey fulfils all other criteria for membership. ${ }^{35}$ This feeling helped legitimize the view that the EU is now discriminating against Turkey; in the past, the EU has never adopted such a criterion with respect to other candidate states.

Fifth, the decision of the French parliament to criminalize people who deny the so-called "Armenian genocide" has further exacerbated Turkey's frustration. Both the Kemalist secular elites and the AKP government are strongly against the idea that Turkey's accession to the Union be dependent on its a priori recognition of Armenian allegations.

Sixth, a particular development that has contributed to the erosion of the AKP's instrumental logic took place when the European Court of Human Rights (ECHR) 
ruled in favor of the decisions of the Turkish courts to ban the wearing of turbans in universities. Initially, the AKP supported those who appealed to this court with regard to the banning of headscarves in Turkish universities. The assumption on the part of AKP was that the ECHR would rule against the decisions of the Turkish courts.

The logic of interest adopted in the formulation of Turkey's foreign policy towards the United States has also experienced setbacks for various reasons, of which the diverging Turkish and US understandings of the end result of the liberaldemocratic transformation process in the Middle East comes first. Turkey simply fears that in the absence of internal dynamics, immediate democratization attempts in the region would result in chaos and anarchy, if not in the eventual dismemberment of current regimes. From Ankara's perspective, an externally oriented democratization attempt would likely bring into power radical Islamists or ethnic separatists, an outcome that the United States hopes to prevent, in its war on radical terrorism. ${ }^{36}$ The developments in Iraq offer examples in this regard. ${ }^{37}$ Turkey and the United States have also disagreed on to how to shape Iraq's internal order and its relations with neighboring countries. ${ }^{38}$ In Turkey's view, the post-Saddam era of Iraq should not be based on a weak federal arrangement in which the prospects of independent Kurdish rule in the north remain strong. The command of the center over the whole country should be guaranteed, even if Iraq's division into separate sovereign states appears to some Americans as a viable strategy. From Ankara's perspective, the US government should support Turkey's military struggle against PKK presence in northern Iraq, even if it risks the functional cooperation between Washington and Erbil. Suggestions by the United States that Turkey should, above all, find an internal solution to the PKK terrorism and engage in a diplomatic relationship with the representatives of the Kurdish Regional Government have not been perceived positively in Ankara. Ankara has long expected that Washington put pressure on the Kurdish leadership in Erbil to accommodate Turkey's concerns in the region. ${ }^{39}$ After months, if not years, of painstaking negotiations on all fronts, the Turks and the Americans have developed a common understanding, particularly on the need to eradicate the PKK from northern Iraq, a situation that constituted the biggest roadblock to cooperation among Turks, Kurds, and Americans.

Ankara and Washington have also been at odds with respect to the optimal strategy towards Iran. While Ankara has long supported the EU-led constructive engagement approach and argued for Iran's gradual reintegration into global society, the United States has simply defined Iran as an existential threat that needs to be contained at all costs. From Ankara's point of view a nightmare scenario would occur if the United States government asked Ankara to downgrade its improving economic relations with Tehran, if not to side with Washington in a military campaign against the regime. Seen from this angle it is no surprise that US objections to the Turkish-Iranian gas deal signed in July 2007 have irked Ankara. ${ }^{40}$

Another point of disagreement between Turkey and the United States concerns Syria. While US administrations have long defined Syria as a terrorist and "rogue state" and declined to join with the Asad regime through economic and diplomatic 
means, Turkey has developed the view that peace in the Middle East requires the active participation of the Syrian regime in the process. Turkey does not want to see its improving relations with Syria-mainly owing to Syria's giving in to Turkish pressure to expel the head of PKK, Abdullah Öcalan, from its territories-damaged by the growing tension between Washington and Damascus.

Moreover, while the AKP government has recognized the results of the elections held in the Palestinian Territories in early 2006, the US administration has declined to recognize Hamas, which was victorious in the elections, as the legitimate representative of the Palestinian people. In the eyes of the Americans, Hamas is only a terrorist organization. Turkey has also been at odds with the United States whenever the Turkish governments have harshly criticized the level of violence inflicted upon the Palestinian people by Israeli security forces.

The view that Turkey's improving relations with Russia might be impaired by the growing tension between the West and Russia offers another justification for the erosion of the logic of interest towards the West. Turkey does not want to view Russia simply through the glasses of the West. Regional antipathy towards the West has recently helped Turkey and Russia to come closer. Russia, under Putin's presidency from May 2000 to May 2008, followed a Eurasianist foreign policy, the ultimate goal of which is to reclaim Russia's loss of power and prestige in international politics. Russia has grown skeptical of Western policies in the Black Sea, the Caucasus, and the Middle Eastern regions. Feelings of encirclement and isolation have formed in Moscow. In its drive to free itself of such Western policies, Russia has approached Turkey as a potential ally. Both countries believe that the West treats them instrumentally; both feel frustrated by Western attempts to contain and isolate them. Both view the US-led "color revolutions" with skepticism. ${ }^{41}$ Both are discontent with growing US efforts to reach out to the Black Sea region as the dominant security player. Unlike their relations with Western statesmen, Russian and Turkish statesmen treat each other with respect. Turkey is now dependent on Russian natural gas. The trade volume between the two countries currently amounts to US\$20 billion. Russian tourists have outpaced Germans in visiting Turkey. Some analysts even argue that Russia has finally reached warm water through its people visiting Turkey's southern coasts. ${ }^{42}$ The Turkish military has even put former Russian president Putin's speech, delivered at the Munich Security conference in February 2007, on its official website. In that speech, Putin harshly criticized the unilateral and coercive US foreign policies in the post-September 11 era and put the main blame for growing global instability and chaos on Washington's policies.

In addition, there are now some influential circles inside Turkey, most notably some retired generals, who argue that Turkey should leave NATO and try to form strategic security relationships with Russia, China, and Iran, most probably within the framework of the Shanghai Cooperation Organization. ${ }^{43}$ To them, NATO has lost its Cold-War era strategic rationale, and Turkey and the United States have adopted diametrically opposing views on as many issues as possible. Turkey's ability to develop closer relations with the geopolitical powers of Eurasia, namely Russia, China, and Iran, is now negatively affected by NATO's post-Cold War era 
transformation because this transformation is based on the idea that these countries might potentially be the rivals of the West in the future and therefore need to be contained.

\section{Conclusion}

This study has mainly argued that the decades-long ideational logic towards the EU and NATO is gradually losing its legitimacy in Turkey as the changing dynamics of Turkey's relations with the West no longer guarantee Turkey's Western/European identity. The latest trends suggest that the West now sees Turkey more as part of the Greater Middle Eastern region than part of Europe. Combined with the growing legitimacy of Eurasian identity at home, the West's approach towards Turkey has gradually led Turkish foreign policy-makers to adopt a logic of interest towards the West. Public opinion polls by the German Marshall Fund carried out between 2005 and 2009 almost steadily reveal that even Turkey's instrumental cooperation with the West cannot be taken for granted. ${ }^{44}$ Turks were also found to be the most pessimistic regarding the prospects of Turkey's accession to the EU.

What Turkey is now experiencing in its relations with the leading members of the Western world, namely the EU and the United States, is quite extraordinary. On the one hand, Turkey has come closer to the EU in an institutional sense; on the other hand, a growing number of Turkish people question the EU's true intentions behind the accession process. Similarly, while Turkey is trying to improve its tarnished relations with the United States in the post-Iraq War era, strong reservations are surfacing regarding the true intentions of the United States in the region.

With these changes in mind many Turks are asking the following questions: Does the accession process reflect a rational logic in the sense that the EU would admit Turkey once the accession criteria are fulfilled? Is the sole purpose for placing Turkey in the accession process to exert a dominating influence on Turkey's behaviors? Does the United States want to see a divided Iraq, with its north ruled by an independent Kurdish government? These are legitimate questions that many Turks have on their minds. What is potentially worrying is that if no satisfactory answers are found in a reasonable time period, a significant majority of Turkish people may interpret the decades-long Westernization and/or Europeanization process as producing insecurity rather than security.

\section{Notes}

1. Most authors use the term "war of independence" to define the period of a series of Turkish military campaigns against occupying powers from 1920 to 1922. It is possible for there to be no difference between a "war of liberation" and a "war of independence" as long as both lead the way to the liberation of a territory from foreign occupation. Yet "war of independence" is a more suitable term for people fighting for their freedom against colonial powers who have ruled for extended periods. In the case of the Turkish War of Liberation one must bear in mind that the Turks, who built empires (the Seljuks, the Ottomans), have never been colonized or ruled by outside powers. One exception is a short period of foreign occupation of the last pieces of Ottoman lands (mostly in Anatolia) as a result 
of the surrender of the defeated Ottoman Sultan at the end of the World War I. His decision was by no means accepted by the Ottoman military officer of the time, Mustafa Kemal, and his like-minded comrades and followers, who launched a national resistance movement at first and then an all-out offensive over the Turkish territory delineated by Treaty of Sevres (dated August 10, 1920). Mustafa Kibaroğlu and Ayşegül Kibaroğlu, Global Security Watch - Turkey: A Reference Handbook (Westport, CT: Praeger Security International, 2009), pp. 1-2.

2. Ali L. Karaosmanoğlu, "The Evolution of the National Security Culture and the Military in Turkey," Journal of International Affairs, Vol. 54, No. 1 (2000), pp. 199-217.

3. The Tanzimat movement (1839-1871) introduced reforms to the Ottoman administration and society under pressure from the European powers by Sultan Abdülmecid-I (1839-1861) and Sultan Abdulaziz (1861-1876). Accordingly, the Ottoman army was reorganized according to the Prussian model, the taxation system was overhauled, and representative assemblies from the provinces were created. As part of the reforms, French criminal and commercial laws inspired the Ottoman administration to introduce a penal code applicable in the new state courts, which were separate from the religious courts. See, for instance, Ethem Eldem, "Ottoman Financial Integration with Europe: Foreign Loans, the Ottoman Bank and the Ottoman Public Debt," European Review, Vol. 13, No. 3 (2005), pp. 431-45.

4. The use of the acronym "AKP" for the Adalet ve Kalkınma Partisi (Justice and Development Party) has become a controversial issue in Turkey, with a powerful statement made by Prime Minister Erdoğan, who is also the leader of the party, condemning those who continue to use AKP as their adversaries. Erdoğan asked everybody to use "AK Parti" instead, which, however, does not make much sense to those who do not understand Turkish. The authors of this article acknowledge the right of the members of the Justice and Development Party as well as those in its cadre of leadership to ask for a particular acronym to be used concerning their party's name and respect their decision. However, for the sake of simplicity and convenience for foreign readers "AKP" will be used throughout the text without any other secondary political or other considerations.

5. Philip Robins, "Turkish Foreign Policy since 2002: Between a 'Post-Islamist' Government and a Kemalist State," International Affairs, Vol. 83, No. 1 (2007), pp. 289-304.

6. Mustafa Aydın, "The Determinants of Turkish Foreign Policy, and Turkey's European Vocation," Review of International Affairs, Vol. 3, No. 2, pp. 306-31.

7. Fuat Keyman, "Modernity, Secularism and Islam," Theory, Culture \& Society, Vol. 24, No. 2, pp. 215-34.

8. Tarık Oğuzlu, "Middle Easternization of Turkey's Foreign Policy: Does Turkey Dissociate from the West?" Turkish Studies, Vol. 9, No. 1 (2008), pp. 3-20.

9. Bary Buzan and Thomas Diez, "The European Union and Turkey," Survival, Vol. 41, No. 1 (1999), pp. 41-57.

10. Ole Wæver, "Integration as Security: Constructing a Europe at Peace," in: Charles A. Kupchan (ed.), Atlantic Security Contending Visions (Washington DC: Council on Foreign Relations, 1998), pp. 45-63.

11. The EU's position in this regard can be found in the Negotiation Framework Document prepared by the European Commission on the eve of the initiation of accession talks with Turkey in October 2005. See http://ec.europa.eu/enlargement/pdf/turkey/st20002_05_tr_framedoc_en.pdf.

12. Richard Youngs, Europe's Flawed Approach to Arab Democracy (London: Centre for European Reform Essays, 2006).

13. Antonio M. Ruiz-Jimenez, "European Public Opinion and Turkey's Accession: Making Sense of Arguments For and Against," European Policy Institute Network, Working Paper No. 16 (2007).

14. Lauren M. McLaren, "Explaining Opposition to Turkish Membership of the EU," European Union Politics, Vol. 8, No. 2 (2007), pp. 251-78.

15. Jorg Monar, "The EU's Approach Post-September 11: Global Terrorism as a Multidimensional Law Enforcement Challenge," Cambridge Review of International Affairs, Vol. 20, No. 2 (2007), pp. 267-83.

16. Oğuzlu. "Middle Easternization of Turkey's Foreign Policy." 
17. Ibid.

18. George E. Gruen, “Turkey's Role in Peacekeeping Missions," American Foreign Policy Interests, Vol. 28, No. 6 (2006), pp. 435-49.

19. Ronald D. Asmus, Larry Diamond, Mark Leonard and Michael McFaul, "A Transatlantic Strategy to Promote Democratic Development in the Broader Middle East," The Washington Quarterly, Vol. 28, No. 2 (2005), pp. 7-21.

20. Kemalists are staunch believers in and followers of the principles of Mustafa Kemal Atatürk and the reforms that he introduced to the Turkish nation during the state-building process, which has resulted in the modern Republic of Turkey from the ashes of the Ottoman Empire.

21. Ömer Taşpınar, “An Uneven Fit? The 'Turkish Model' and the Arab World," Brookings Project on U.S. Relations with the Islamic World, Analysis Paper No. 5 (2003).

22. For instance, despite Turkey's aspirations to be fully involved in the emerging European Security and Defense Policy (ESDP) decision-making mechanisms, the goal on the part of the EU was to make use of Turkey's military and strategic capabilities allocated to NATO as if it were a member of the EU while at the same time avoiding the possibility of Turkey affecting the ultimate decisions of the European powers. However, Turkey resisted that proposal and pursued a policy of conducting tough negotiations with the EU that also involved the United States at later stages.

23. Hasan Kösebalaban, "The Rise of Anatolian Cities and the Modernization Paradigm," Critique: Critical Middle Eastern Studies, Vol. 16, No. 3 (2007), pp. 229-40.

24. Oğuzlu, "Middle Easternization of Turkey's Foreign Policy."

25. Joshua W. Walker, "Learning Strategic Depth: Implications of Turkey's New Foreign Policy Doctrine," Insight Turkey, Vol. 9, No. 3 (2007), pp. 32-47.

26. Kemal Kirişçi, “Turkey’s Foreign Policy in Turbulent Times," Institute for Security Studies, Chaillot Papers 92 (2006), pp. 38-49.

27. Michael Rubin, "Green Money, Islamist Politics in Turkey," Middle East Quarterly, Vol. 12, No. 1 (2005), pp. 13-23.

28. Hasan Kosebalaban, "The Permanent 'Other'? Turkey and the Question of European Identity," Mediterranean Quarterly, Vol. 18, No. 4 (2007), pp. 101-8.

29. Turkish Foreign Minister Ali Babacan's statement during a press conference in Ankara in September 2007.

30. Tarik Oğuzlu and Mustafa Kibaroğlu, "Incompatibilities in Turkish and European Security Cultures Diminish Turkey's Prospects for EU Membership,” Middle Eastern Studies, Vol. 44, No. 6 (2008), pp. 945-62.

31. Bill Park, "Between Europe, the United States and the Middle East: Turkey and European Security in the Wake of the Iraq Crisis," Perspectives on European Politics \& Society, Vol. 5, No. 3 (2004), pp. 493-516.

32. The Annan Plan was a United Nations proposal to settle the dispute of the divided island nation of Cyprus by creating the United Cyprus Republic.

33. Michelangelo Guida, "The Sevres Syndrome and Conspiracy Theories in the Islamist and Secular Press," Turkish Studies, Vol. 9, No. 1 (2008), pp. 37-52.

34. Fatos Tarifa and Benjamin Adams, "Who's the Sick Man of Europe? A Wavering EU Should Let Turkey," Mediterranean Quarterly, Vol. 18, No. 1 (2007), pp. 53-74.

35. "The Absorption Puzzle," Economist, Vol. 380, No. 8484 (July 1, 2006), p. 50.

36. Fareed Zakaria, Özgürlüğ̈̈̈n Geleceği, Yurtta ve Dünyada Illeberal Demokrasi [The Future of Freedom, Illiberal Democracy at Home and Abroad] (İstanbul: Kirmizi Yayinlari, 2007).

37. Hakan M. Yavuz and Nihat Ali Özcan, "The Kurdish Question and Turkey's Justice and Development Party," Middle East Policy, Vol. 13, No.1 (2006), pp. 102-19.

38. Jonathan Eric Lewis, "Replace Turkey as a Strategic Partner?" Middle East Quarterly, Vol. 13, No. 2 (2006), pp. 1-8.

39. Philip Gordon and Ömer Taşpınar, "Turkey on the Brink," The Washington Quarterly, Vol. 29, No. 3 (2006), pp. 57-70. 
40. Turkish Prime Minister Recep Tayyip Erdoğan made a statement along these lines during the Security Conference, which convened in Munich, Germany on February 9, 2008.

41. "Color revolutions" denote the popular movements in the former Soviet republics, namely Georgia and Ukraine, that paved the way for the pro-Western parties in these countries to come to power through general elections. The results of the Georgian elections in 2003 are called the "Rose Revolution" and the results of the Ukrainian elections are called the "Orange Revolution," as these colors are associated with the colors of the flags and banners carried by the supporters of the parties that won the elections with the overwhelming majority of votes.

42. Suat Kınıkloglu, "The Anatomy of Turkish-Russian Relations," http://www.brookings.edu/comm/ events.

43. Retired General Tuncer Kılınç, former secretary general of the then powerful National Security Council (MGK), was on record in March 2002 for suggesting, among other things, forming an alliance with Russia, Iran, and China.

44. The findings of the poll can be found at http://www.transatlantictrends.org. Nearly 80 percent of Turks think that Turkey and the United States are not allies anymore. Similar findings are observed regarding the EU. The number of people supporting Turkey's membership in the EU has fallen from its peak of around 75 percent in 2005 to 55 percent as of early 2008. http://www.gmfus.org/trends/ 2009/docs/2009_English_Key.pdf. 